\title{
Relationship knowledge and attitudes towards willingness to receive COVID-19 vaccination in NTB Province
}

\author{
Fidya Rizka $^{1 *}$, Kristiani Murti Kisid ${ }^{2}$, Endy Bebasari Putri ${ }^{3}$ \\ 1,2,3Program Studi D-IV Kebidanan, Sekolah Tinggi Ilmu Kesehatan Mataram, Indonesia \\ ${ }^{1}$ fidiya22@gmail.com; ${ }^{2 k r i s t i n k i s i d @ g m a i l . c o m * ; ~}{ }^{3}$ bebasari_putri@yahoo.com \\ *Corresponding Author \\ Submission date: 24 Maret 2021, Receipt date: 2 Juli 2021, Publication date: 1 November 2021
}

\begin{abstract}
COVID-19 is one of the diseases with a very high and fast spread that requires vaccination as a protection step. The purpose of this study is to find out the relationship between knowledge and attitude towards willingness to receive COVID-19 vaccination in NTB Province. This research is an Observational research with cross sectional design. The results of this study were the majority of respondents with a level of knowledge $(62.3 \%)$, good attitude $(66 \%)$ willing to receive COVID-19 vaccination. The results of bivariate analysis resulted in a significant relationship between knowledge of COVID-19 vaccination and attitude towards willingness to receive COVID-19 vaccination.
\end{abstract}

Keywords: vaccination; COVID-19; knowledge; attitude

\section{INTRODUCTION}

February 11, 2020 WHO officially announced the disease triggered by 2019nCoV 2019 as Corona Virus Disease 2019 (COVID-19) And on the same day a Study Group from the International community that studied the Coronavirus mentioned 2019$\mathrm{nCoV}$ as a severe acute respiratory syndrome of the type coronovirus 2 (SARS-CoV-2) (Sun et al., 2020). Monday, March 2, 2020 is a historic moment for the people of Indonesia, because on that date the President of the Republic of Indonesia for the first time announced 2 citizens who were positively affected by COVID-19. Covid 19 comes from sars-cov-2 virus which is the result of mutation of SARS-CoV virus that spread in 2002 and MERS-CoV in 2012 (Propetchara et al., 2020). COVID-19 is one of the diseases with a very high and rapid spread so that in just a few weeks this virus has been able to infect almost all citizens in the world is no exception in Indonesia. Not even a year since the announcement of the first case in Indonesia, on February 4, 2020, Indonesia's COVID-19 cases have reached 1,123,959 confirmed cases and 31,001 deaths (2.8\%) (Komite Penanganan Covid-19 dan Pemulihan Ekonomi Nasional, 2021).

At the beginning of the outbreak of the COVID-19 case until mid-February 2020, researchers have not found a successful vaccine to be developed so that treatment focuses on symptomatic treatment. While waiting for effective treatment, the best way to deal with COVID-19 cases is to control the source of infection. By taking this into account, the government's restriction policy appears to minimize the spread of COVID19 in Indonesia. Sun et al in 2020 in their research argued that the spread of COVID-19 could be suppressed by implementing several strategies, namely protection, early detection, isolation and fast treatment (Sun et al., 2020). As a form of protection effort, all countries are committed to involving the government, pharmaceutical companies, scientists and academics to be able to carry out further studies that create a COVID-19 vaccine. Indonesia has also started to build its network to develop a COVID-19 vaccine 
in collaboration with several countries and pharmaceutical companies. One of them is Sinovac, a Biotechnology company from China that collaborates with Bio Farma and the Padjadjaran Faculty of Medicine. In addition, Indonesia also collaborates with a South Korean company, Genexine, which collaborates with Kalbe Farma and the Faculty of Medicine, University of Indonesia and the Indonesian Institute of Sciences (LIPI). On Sunday, 6 December 2020, 1.2 million COVID-19 vaccines made by Sinovac arrived in Indonesia. On January 13, 2021, the official vaccination program began to be carried out by the Indonesian government where President Joko Widodo was the first person to get the vaccine, followed by a number of officials, religious leaders, professional organizations and community representatives.

Rajaratenam et al in 2014 described knowledge as a treasure trove of mental wealth that directly or indirectly enriches our lives. Every knowledge has specific characteristics about what (ontology), how (epistology), and for what (axiology) (Rajaratenam, et al., 2014). The higher a person's knowledge, the positive impact on that person's behavior. A study conducted by Rahayu et al in 2018 found that there was a significant relationship between knowledge and attitudes towards nurse behavior. Good caring behavior can be influenced by the knowledge and attitudes of good nurses about caring (Rahayu, et al., 2018).

Attitude is a person's reaction to a given stimulus. Attitude is also a person's reaction to support or take sides with a given stimulus. Several studies have shown that there is a strong influence between a person's attitude and behavior towards a stimulus. Like the research conducted by Lestari in 2019 with the results that there is a significant relationship between attitude and the act of washing hands (Octa, et al., 2019).

Good knowledge will encourage someone to tend to have good behavior. Knowledge will influence a person to determine what attitudes and behavior he should show in response to a stimulus. When the COVID-19 pandemic hit Indonesia, all health practitioners participated in providing education related to COVID-19 starting from the understanding of COVID-19 itself, how to prevent it to the vaccination program. With the education provided by health practitioners, it is hoped that the public will have sufficient knowledge to be able to take a stand and determine the right behavior towards the vaccination program stimulus that has been announced. Therefore research is related to knowledge, attitudes and the willingness of the community to get vaccinated against COVID-19 in NTB Province in 2021. The purpose of this study is to determine the relationship between knowledge and attitudes towards willingness to receive COVID-19 vaccination in NTB Province.

\section{RESEARCH METHODS}

This research is an observational study with a cross sectional design. The sample in this study were people who live in NTB Province and are willing to be respondents with a total of 77 respondents. This study uses primary data with a research instrument in the form of a questionnaire made with the google form application and distributed through social media. Respondents will fill out the online form willingness to be respondents first before entering the questionnaire form. The independent variable in this study is the level of knowledge and attitude with the results of measuring good, sufficient, insufficient knowledge and good or poor attitudes.

Data processing in this study was carried out using editing, coding, and data entry steps. Data analysis used univariate and bivariate analysis. Bivariate analysis was 
used to determine the relationship between research variables using the Chi-square test with a degree of significance $p<0.05$.

\section{RESULTS AND DISCUSSION}

\section{Characteristics of Respondents}

Most respondents are in the age group 26 to 45 years $(77.9 \%)$ where this age group is still the productive age group. Most of the respondents $(61 \%)$ were female. And 27 respondents $(35 \%)$ are at the last level of education, namely Bachelor, followed by SMA $(24.7 \%)$.

Table 1. Characteristics of Respondents

\begin{tabular}{cccc}
\hline Variabel & Kategori & $\mathbf{N}$ & \% \\
\hline Age (years) & $12-25$ & 10 & 13 \\
& $26-45$ & 60 & 77,9 \\
\multirow{3}{*}{ Gender } & $46-65$ & 7 & 9,1 \\
& Female & 47 & 61 \\
Last education & Male & 30 & 39 \\
& SMP & 1 & 1,3 \\
& SMA & 19 & 24,7 \\
& Diploma & 14 & 18,2 \\
& Bachelor & 27 & 35,1 \\
& Masters & 16 & 20,8
\end{tabular}

Source: Primary Data

2. Level of public knowledge about COVID-19 Vaccination

Table 2. Level of Public Knowledge about COVID-19 Vaccination

\begin{tabular}{cccc}
\hline No. & Knowledge & $\mathbf{N}$ & \% \\
\hline 1 & Good & 48 & 62,3 \\
2 & Enough & 24 & 31,2 \\
3 & Less & 5 & 6,5 \\
\hline
\end{tabular}

Source: Primary Data

The results of this study indicate that the knowledge of the NTB Provincial Community about COVID-19 Vaccination is in the good category (62.3\%), moderate $(31.2 \%)$ and only $6.5 \%$ is in the poor category. These results indicate that the knowledge of the people of NTB Province regarding the COVID-19 vaccination is on average in the good and sufficient category. The results of this study are in line with the results of research presented by Purnamasari et al in 2020, namely that $90 \%$ of public knowledge about COVID-19 is in the good category (Purnamasari, et al., 2020). People who have good knowledge will have a good attitude and be followed by good behavior too. This good and sufficient level of knowledge is also supported by the last education of the respondents, who on average are at Diploma and bachelor levels. With good knowledge of something, a person will have the ability to determine the attitudes and behaviors that will be presented in response to a stimulus on the same material. Someone who has good knowledge about COVID-19 vaccination will be the capital to make decisions regarding their attitudes and behavior towards willingness to be vaccinated. The results of this study are also in line with the results of research conducted by Yanti et al on 150 communities in Sumerta Kelod Village, Denpasar, with the results that the level of public knowledge about the COVID-19 pandemic is in a good category, namely $70 \%$ 
coupled with community behavior that has complied with the protocol health during the COVID-19 pandemic (Yanti, et al., 2020).

\section{Public Attitudes about COVID-19 Vaccination}

Table 3. Attitudes of the People of the Provinsce of NTB regarding COVID-19 Vaccinatioan

\begin{tabular}{cccc}
\hline No. & Attitude & $\mathbf{N}$ & \% \\
\hline 1 & Good & 66 & 85,7 \\
2 & Enough & 1 & 1,3 \\
3 & Less & 10 & 13 \\
\hline
\end{tabular}

Source: Primary Data

The results of this study show that $66 \%$ of respondents have a good attitude towards COVID-19 vaccination and only $13 \%$ have a lack of attitude about COVID19 vaccination. The results of this study indicate that the attitudes of most respondents are in the good category, this result is in line with the results of research conducted by Sukesih et al in 2020 on 444 respondents with a knowledge level of $51.35 \%$ in the good category and $46.39 \%$ of respondents having good attitude so that the prevention of transmission of COVID-19 can be done maximally (Sukesih, et al., 2020). Good knowledge will lead to a good attitude to be able to determine the right behavior in response to a stimulus (Peng, et Al., 2020). A person's attitude can be influenced by several factors including personal experience and social environment. A person who has experienced a disease tends to be more alert to contract it again so that his attitude towards treatment and prevention of re-exposure will be better. Likewise with the social environment, if someone is in a social environment with a positive attitude, it can have an impact on that person's attitude to be influenced by other people who have a positive attitude in preventing disease (Hasanah and Sri., 2017).

\section{Willingness to vaccinate COVID-19}

Table 4. Community Willingness to be Vaccinated

\begin{tabular}{cccc}
\hline No. & $\begin{array}{c}\text { People's Willingness to } \\
\text { Vaccine }\end{array}$ & N & \% \\
\hline 1 & Yes & 42 & 54,5 \\
2 & No & 35 & 45,5 \\
\hline
\end{tabular}

Source: Primary Data

The results of this study indicate that 42 respondents $(54.5 \%)$ of the community are willing to receive COVID-19 vaccination. These results are in line with the results of research conducted by Pradono et al. 2013, with the results that knowledge of health $(51.6 \%)$, healthy behavior $(48.2 \%)$, and education level (47.1\%) contributed $55 \%$ of a person's health status (Pradono and Ning., 2013).

\section{Relationship between Knowledge and Attitude and Willingness to Receive COVID-19 Vaccination}

Table 5. Relationship between Knowledge and Willingness to Receive COVID-19 Vaccination

\begin{tabular}{cccccccc}
\hline Knowledge & \multicolumn{7}{c}{ Willingness to Receive Vaccines } \\
\cline { 2 - 7 } & yes & \% & no & \% & Total & \% & P Value \\
\hline Good & 28 & 58,3 & 20 & 41,7 & 48 & 100 &, 040 \\
Enough & 14 & 58,3 & 10 & 41,7 & 24 & 100 & \\
Less & 0 & 0 & 5 & 100 & 5 & 100 & \\
\hline
\end{tabular}

Source: Primary Data 
The results of the analysis in the table above show that $58.3 \%$ of respondents who have good knowledge and are quite willing to receive COVID-19 vaccination and $100 \%$ of respondents who have less knowledge are unwilling to receive COVID-19 vaccination. The results of the Chi Square statistical test with a confidence level of $95 \%$ obtained a $P$ value of $0.40(p<\alpha)$, which means that there is a significant relationship between knowledge and a person's willingness to receive COVID-19 vaccination. These results are in line with the results of research by Purnamasari et al, which showed that there was a significant relationship between knowledge and people's behavior about COVID-19 (Purnamasari and Raharyani., 2020). Another research that supports the results of this study is research conducted by Yanti B, et al (2020) which states that $99 \%$ of Indonesians have good knowledge, $59 \%$ have a positive attitude and $93 \%$ have good behavior towards efforts to prevent COVID-19 (Yanti, et al., 2020). In Indonesia with social distancing. This good level of knowledge is supported by a high level of education (diploma and bachelor's degree), where a high level of education will make it easier for someone to gain access to information. The level of knowledge that is supported by a good level of education will influence a person's behavior in responding to a stimulus.

Other research also shows that there is a relationship between knowledge and a person's behavior, namely research conducted by Zhong BL (2020) and the research subject is the Chinese community as the initial place for the discovery of the COVID-19 case. This can be seen from how the Wuhan community faced other cases of the SARS-CoV virus in the previous year so that they could rise faster (Zhong, et al., 2020). Good knowledge will be influenced by how the information is given and received by someone. Sulistyaningtyas (2020) in his research shows that differences in social class will have an impact on the acceptance of information which in turn has an influence on a person's level of knowledge (Ningsih, et al., 2018).

Table 6. Relationship attitude with willingness Receiving Vaccination COVID-19

\begin{tabular}{|c|c|c|c|c|c|c|c|}
\hline \multirow[t]{2}{*}{ Attitudes } & \multicolumn{5}{|c|}{ willingness Receiving Vaccination } & \multirow[b]{2}{*}{$\%$} & \multirow[b]{2}{*}{$P$ Value } \\
\hline & Yes & $\%$ & No & $\%$ & Total & & \\
\hline Good & 41 & 62,1 & 25 & 37,8 & 66 & 100 &, 001 \\
\hline Enough & 1 & 100 & 0 & 0 & 1 & 100 & \\
\hline Less & 0 & 0 & 10 & 100 & 77 & 100 & \\
\hline
\end{tabular}

Source: Primary Data

The results of the analysis in this study show that $62.1 \%$ of respondents who have a good attitude are willing to receive COVID-19 vaccination. And 100\% of respondents with less knowledge are not willing to accept COVID-19 vaccination. These results are in line with the results of research conducted by Sukesih et al (2020) which found that good knowledge $(51.35 \%)$ and a good attitude $(46.39 \%)$ can help in preventing the transmission of COVID-19 in Indonesia. Good knowledge about COVID-19 can reduce negative emotions in facing the risk of an outbreak with a more positive attitude so that it will affect a person's behavior towards COVID-19 (Akdeniz, et al., 2020). Other research results that are in line with this study are the results obtained by Ssebuufu et al (2020), namely $83.9 \%$ of respondents with good knowledge and $72.4 \%$ of respondents with good attitudes have practical behavior in preventing the spread of COVID-19 more actively (Sebufu et al., 2020). 
The COVID-19 vaccination program has been implemented by the Indonesian government which started in January 2021 where the President of the Republic of Indonesia was the first person to get the vaccination followed by government officials, health practitioners, community representatives and public figures. Vaccination is the most effective and economical way to prevent infectious diseases (Makmun and Hazhiyah, 2020). The safety of the vaccine with a rapid development and testing process needs to be considered, this problem must be addressed immediately before and after the vaccine program is launched. The public must know transparently about the rigorous testing of vaccines and the necessary sustainability monitoring so as to increase public confidence in the vaccination program. Health education related to the COVID-19 vaccination program must be carried out so that people have good knowledge regarding COVID-19 vaccination which will make a positive contribution to good attitudes to become the basis for determining willingness behavior to receive COVID-19 vaccination (Deroo Sarah, et al., 2020).

\section{CONCLUSION}

Based on this research, it can be concluded that there is a significant relationship between knowledge and attitudes towards the willingness to receive the COVID-19 vaccination in NTB Province. The need for consistency in providing health education related to COVID-19 and the COVID-19 vaccination program by health practitioners and the public so as to increase public awareness of the importance of COVID-19 vaccination to break the chain of COVID-19 spread. With knowledge about COVID-19 vaccination, it will make a positive contribution to a good attitude and produce good behavior, namely being willing to be vaccinated against COVID-19.

\section{REFERENCES}

Akdeniz, G., Kavakci, M., Gozugok, M., Yalcinkaya, S., Kucukay, A., \& Sahutogullari, B. (2020). A Survey of Attitudes, Anxiety Status, and Protective Behaviors of the University Students During the COVID-19 Outbreak in Turkey. Frontiers in Psychiatry, 11(July), 1-9. https://doi.org/10.3389/fpsyt.2020.00695

DeRoo Sarah Scaffer, Natalie J Pudalov, Linda Y. Fu. (2020). Planning For a COVID19 Vaccination Program. JAMA. 323 (24). 2458-2459.

Hasanah Intan Nugraheni, Sri Wahyuni. (2017). Hubungan Pengetahuan dan Sikap dengan Perilaku Pencegahan Infeksi Leptospirosisi Pada Ibu Hamil. Jurnal Kebidanan. Vol. 6 (12). 55-62

Kisid, K. (2021). Profile of Violence of Women and Children in the COVID-19 Pandemic Period in NTB Province. EMBRIO, 13(1), 64-70. https://doi.org/10.36456/embrio.v13i1.3294

Kisid, K., \& Endy Bebasari Ardhana Putri. (2021). KEJADIAN COVID-19 BERDASARKAN KARAKTERISTIK PENGUNJUNG POLI ISPA PUSKESMAS PERAMPUAN LOMBOK BARAT. Jurnal Penelitian Dan Kajian Ilmiah Kesehatan Politeknik Medica Farma Husada Mataram, 7(2), 
169-175.

Retrieved

from

https://jurnal.poltekmfh.ac.id/index.php/JPKIK/article/view/276

Komite Penanganan COVID-19 dan Pemulihan Ekonomi Nasional. Situasi COVID-19 DI Indonesia. Update 4 Februari 2021 pukul 14.00. https://covid19.go.id/p/berita.

Makmun, A., \& Hazhiyah, S. F. (2020). Paragraf 1. Molucca Medica, 13, 52-59.

Ningsih, E. S. B., \& Hennyati, S. (2018). Kekerasan Seksual Pada Anak Di Kabupaten Karawang [Sexual Violence of Children In Karawang District]. Midwife Journal, 4(02), 56-65. http://jurnal.ibijabar.org/kekerasan-seksual-pada-anak-dikabupaten-karawang/

Octa, A. (2019). Hubungan Pengetahuan Dan Sikap Terhadap Perilaku Cuci Tangan Pada Masyarakat Kelurahan Pegirian. Jurnal PROMKES, 7(1), 1. https://doi.org/10.20473/jpk.v7.i1.2019.1-11

Peng, Y., Pei, C., Zheng, Y., Wang, J., Zhang, K., Zheng, Z., \& Zhu, P. (2020). A crosssectional survey of knowledge, attitude and practice associated with COVID-19 among undergraduate students in China. BMC Public Health, 20(1), 1-13. https://doi.org/10.1186/s12889-020-09392-z

Pradono Julianty, Ning Sulistyowati. (2013). Hubungan Antara Tingkat Pendidikan, Pengetahuan Tentang Kesehatan Lingkungan, Perilaku Hidup Sehat dengan Status Kesehatan. Studi Korelasi pada Penduduk Umur 10-24 Tahun di Jakarta Pusat. Buletin Penelitian Sistem Kesehatan. Vol. 17 (1). 89-95

Prompetchara, E., Ketloy, C., \& Palaga, T. (2020). Immune responses in COVID-19 and potential vaccines: Lessons learned from SARS and MERS epidemic. Asian Pacific Journal of Allergy and Immunology, 38(1), 1-9. https://doi.org/10.12932/AP-200220-0772

Purnamasari, I., \& Raharyani, A. E. (2020). Tingkat Pengetahuan Dan Perilaku Masyarakat Kabupaten Wonosobo Tentang Covid -19. Jurnal Ilmiah Kesehatan, 3(1), 33-42. https://ojs.unsiq.ac.id/index.php/jik/article/view/1311

Rahayu, S. (2018). Hubungan Pengetahuan dan Sikap dengan Perilaku Caring Perawat di Rumah Sakit. Faletehan Health Journal, 5(2), 77-83. https://doi.org/10.33746/fhj.v5i2.12.

Rajaratenam, S. G., Martini, R. D., \& Lipoeto, N. I. (2014). Hubungan Tingkat Pengetahuan dan Sikap dengan Tindakan Pencegahan Osteoporosis pada Wanita Usila di Kelurahan Jati. Jurnal Kesehatan Andalas, 3(2), 225-228. https://doi.org/10.25077/jka.v3i2.96

Ssebuufu, R., Sikakulya, F. K., Mambo, S. B., Wasingya, L., Nganza, S. K., Ibrahim, B., \& Kyamanywa, P. (2020). Knowledge, Attitude, and Self-Reported Practice Toward Measures for Prevention of the Spread of COVID-19 Among Ugandans: 
A Nationwide Online Cross-Sectional Survey. Frontiers in Public Health, 8, 128. https://doi.org/10.3389/fpubh.2020.618731

Sukesih, S., Usman, U., Budi, S., \& Sari, D. N. A. (2020). Pengetahuan Dan Sikap Mahasiswa Kesehatan Tentang Pencegahan Covid-19 Di Indonesia. Jurnal Ilmu Keperawatan Dan Kebidanan, $11(2), \quad 258$. https://doi.org/10.26751/jikk.v11i2.835

Sun, P., Lu, X., Xu, C., Sun, W., \& Pan, B. (2020). Understanding of COVID-19 based on current evidence. Journal of Medical Virology, 92(6), 548-551. https://doi.org/10.1002/jmv.25722

Yanti, B., Wahyudi, E., Wahiduddin, W., Novika, R. G. H., Arina, Y. M. D., Martani, N. S., \& Nawan, N. (2020). Community Knowledge, Attitudes, and Behavior Towards Social Distancing Policy As Prevention Transmission of Covid-19 in Indonesia. Jurnal Administrasi Kesehatan Indonesia, 8(2), 4. https://doi.org/10.20473/jaki.v8i2.2020.4-14

Zhong, B. L., Luo, W., Li, H. M., Zhang, Q. Q., Liu, X. G., Li, W. T., \& Li, Y. (2020). Knowledge, attitudes, and practices towards COVID-19 among chinese residents during the rapid rise period of the COVID-19 outbreak: A quick online crosssectional survey. International Journal of Biological Sciences, 16(10), 17451752. https://doi.org/10.7150/ijbs.45221. 